\title{
PELATIHAN APLIKASI MANAJEMEN REPRODUKSI UNTUK PENINGKATAN PRODUKTIVITAS PETERNAK KAMBING PERAH KECAMATAN CIMALAKA, KABUPATEN SUMEDANG
}

\author{
Rini Widyastuti ${ }^{1,2}$, Mohammad Ghozali $^{3}$ \\ ${ }^{\# 1}$ Laboratorium Reproduksi dan Inseminasi Buatan, Departemen Produksi Ternak, Fakultas Peternakan, \\ Universitas Padjadjaran \\ Jl Raya Bandung Sumedang Km 21, Jatinangor, Sumedang Jawa Barat \\ ${ }^{1}$ r.widyastuti@unpad.ac.id@unpad.ac.id \\ ${ }^{\# 2}$ Progam Studi Kedokteran Hewan, Fakultas Kedokteran, Universitas Padjadjaran \\ Jl Raya Bandung Sumedang Km 21, Jatinangor, Sumedang Jawa Barat \\ ${ }^{*}$ Departemen Ilmu Kedokteran Dasar, Fakultas Kedokteran, Universitas Padjadjaran,
}

Jl Raya Bandung Sumedang Km 21, Jatinangor, Sumedang Jawa Barat

moh.ghozali@unpad.ac.id

\begin{abstract}
Abstrak
Peternakan kambing perah merupakan mata pencaharian utama masyarakat Kecamatan Cimalaka, Kabupaten Sumedang disanping produk pertanian. Pengelolaan peternakan dilakukan dengan cara tradisional dan belum menerapkan manajemen reproduksi secara menyeluruh dan komprehenship sehingga hasil yang diperoleh belum optimal. Terbatasnya aplikasi manajemen reproduksi ini disebabkan oleh minimnya pengetahuan dan kesadaran masyarakat peternak terhadap hal tersebut. Salah satu upaya untuk peningkatan hasil tersebut adalah dengan meningkatkan kesadaran masyarakat. Berdasarkan kondisi tersebut maka perlu dilakukan penyuluhan tentang aplikasi manajemen reproduksi dan pelatihan kepada masyarakat seempat untuk mengolah bahan alam yang ada. Kegiatan diawali dengan survei lokasi, pemberian vitamin pada kambing perah, penyuluhan, pengisian kuesioner, pengolahan hasil kuesioner. Hasil menunjukkan bahwa tangka pengetahuan peternak manajemen dan teknologi peroduksi masih sangat minim. Pengetahuan mereka tentang penerapan manajemen reproduksi dala pengeliolaan ternak kambing mengalami peningkatan yang cukup significan pasca pemberian penyuluhan.
\end{abstract}

Kata kunci: kambing perah, manajemen reproduksi, peternak

\section{PENDAHULUAN}

Meningkatnya permintaan produk pangan asal hewan dalam bentuk daging dan susu menjadi sebuah peluang yang menjanjikan dalam bidang usaha peternakan. Kambing yang memiliki potensi untuk dikembangkan adalah kambing Peranakan Ettawa (PE). Kambing PE merupakan kambing tipe perah yang memiliki fungsi ganda, yaitu sebagai penghasil anak dan daging serta sebagai penghasil susu. Dilihat dari tingkat produktivitas, kambing ini memiliki jumlah anak sekelahiran berkisar $1-3$ dan memiliki potensi menghasilkan susu yang lebih besar dari kebutuhan anaknya (Devendra dan Burns, 1994). Anak kambing digunakan untuk memenuhi permintaan daging, sementara disisi lain dengan berkembangnya opini masyarakat tentang khasiat susu kambing untuk menyembuhkan beberapa penyakit, kemudian membuat susu kambing memiliki nilai ekonomis yang menjanjikan pula (Amiyati, 2001). Apabila dibandingkan dengan kambing perah atau hewan besar lainnya kambing memiliki keunggulan komparatif berupa kecepatan pertambahan populasi, dapat dikembangkan pada lahan yang sempit, dan membutuhkan biaya investasi dan pemeliharaan yang sedikit. Keunggulan tersebut membuat kambing dapat dikembangkan oleh peternak rakyat dalam skala kecil dan dapat dilakukan secara masal. Hal ini menjadikan kambing memiliki potensi besar sebagai salah satu penyumbang daging yang sejalan dengan program pemerintah tentang Swasembada Daging (BPS., 2011).

Berdasarkan nilai ekonomis kambing PE yang menjanjikan, saat ini terjadi kecenderungan penurunan populasi akibat tingginya permintaan dan lambatnya laju pertambahan populasi kambing. Hal ini salah satunya disebabkan oleh karena manajemen reproduksi yang belum dilakukan secara optimal dan menemui beberapa masalah pelaksanaan di lapangan. Salah satu daerah yang menjadi sentra peternakan kambing perah di Jawa Barat adalah di Cimalaka Sumedang. Di daerah Cimalaka tersebut, terdapat tiga kelompok tani ternak yang mengelola kambing perah dan pertanian secara terintegrasi. Salah satunya adalah kelompok Tani "Simpay Tampomas".

Penanganan ternak kambing perah di Kelompok Tani "Sympai Tampomas" masih dilakukan secara tradisional dan berdasarkan pada pengetahuan yang diperoleh secara turun temurun (Yunita et al., 2017). Kondisi demikian menyebabkan populasi kambing yang ada di daerah tersebut kurang berkembang, 
sehingga diperlukan peningkatan dan pemberdayaan masyarakat peternak tersebut untuk menerapkan manajemen reproduksi yang tepat dan sesuai dengan kondisi daerah mereka. Minimnya pengetahuan yang dimiliki oleh kelompok masyarakat peternak tersebut, mendorong kami untuk mensosialisasikan prinsipprinsip penerapan manajemen reproduksi pada peternakan kambing perah yang selama ini masih dikelola secara tradisional.

\section{II.TARGET DAN LUARAN}

Berasarkan uraian di atas, maka target dan luaran utama yang kami tentukan pada kegiatan pengabdian masyarakat ini adalah peningkatan pengetahuan dan kesadaran masyarakat untuk aplikasi manajemen reproduksi pada peternakan kambing perah yang mereka kelola. Upaya pencapaian target tersebut diantaranya adalah dengan terlebih dahulu mengetahui data dasar kondisi peternak dan kebutuhan dasar peternak tentang informasi aplikasi manajemen reproduksi. Target dan luaran tersebut secara komprehensip kami sajikan pada Tabel 1.

Tabel 1. Tarket dan luaran kegiatan pengabdian masyarakat unuk aplikasi manajemen reproduksi kambing perah.

\begin{tabular}{|c|c|c|}
\hline No & Target & Luaran \\
\hline 1. & $\begin{array}{lr}\text { Mengetahui } & \text { kondisi } \\
\text { umum peternak dan } \\
\text { peternakan kambing } \\
\text { perah di kelompok } \\
\text { tani } \\
\text { tampomas" }\end{array}$ & $\begin{array}{l}\text { Data kondisi umum peternak } \\
\text { dan peternakan di kelompok } \\
\text { Tani "Sympai tampomas" }\end{array}$ \\
\hline 2. & $\begin{array}{lr}\text { Mengetahui } & \text { tingkat } \\
\text { pengetahuan } & \\
\text { masyarakat } & \text { terdadap } \\
\text { aplikasi manajemen } \\
\text { reproduksi } & \text { pada } \\
\text { peternakan kambing } \\
\text { perah yang mereka } \\
\text { kelola }\end{array}$ & $\begin{array}{l}\text { Data tingkat pengetahuan } \\
\text { anggota kelompok Tani } \\
\text { :Sympai Tampomas" tentang } \\
\text { aplikasi } \\
\text { reproduksi }\end{array}$ \\
\hline 3. & $\begin{array}{l}\text { Peningkatan } \\
\text { pengetahuan peternak } \\
\text { kambing perah tentang } \\
\text { aplikasi manajemen } \\
\text { reproduksi }\end{array}$ & $\begin{array}{l}\text { Meningkatnya pengetahuan } \\
\text { dan kesadaran masyarakat } \\
\text { untuk mengaplikasikan } \\
\text { manajemen reproduksi pada } \\
\text { peternakan kambing perah }\end{array}$ \\
\hline
\end{tabular}

\section{III.MATERI DAN METODE}

\section{Waktu dan Lokasi}

Kegiatan pengabdian dilaksanakan dari bulan Juli- November 2018 di Kelompok Peternak Kambing PE "Simpay Tampomas" yang berlokasi di lereng Gunung Tampomas, Cimalaka, Sumedang, Jawa Barat. Populasi ternak kambing perah cukup banyak sekitar 400 ekor dan dikelola olek 35 Kepala keluarga. Pengelolaan masih tradisional dan kurang memperhatikan Good Farming Practice dan Susu yang diproduksi masih belum diolah dan dikelola ala kadarnya. Masyarakat di daerah tersebutm, punya animo yang cukup untuk belajar mengelola ternak secara terpadu (Widyastuti et al., 2017)

\section{Metode Pelaksanaan}

Kegiatan pengabdian masyarakat ini dilaksanakan dengan metode berikut:

1. Melakukan survey dann kuisioner untuk mendapatkan informasi dasar dan kondisi umum peternak.

2. Penyuluhan tentang manajemen dan aplikasi teknologi reproduksi pada peternakan kambing perah

3. Melakukan pre-test dan post-test untuk mengevaluasi tingkat pengetahuan peternak terhadap aplikasi manajemen reproduksi pada pengeloaan peternakan kambing perah.

Pemberian pretest posttest untuk melihat tingkat pengetahuan masyarakat terhadap apliasi manajemen reproduksi pada kambing perah

\section{HASIL DAN PEMBAHASAN}

Pada awal kegiatan dilakukan survey kondisi umum masyarakat Kelompok tani "Sympai tampomas". Anggota kelompok ini mayoritas adalah wanita dengan Pendidikan sekiolah dasar. Ternak kambing perah mayoritas dikelola secara intensif dengan kandang panggung yang ada di sekitar rumah dengan diberi pakan hijauan yang diperoleh dari kebun. Hanya $20 \%$ peternak yang melakukan pencatatan secara rutin aktivitas ternak kambing perah yang mereka miliki (Tabel 2).

Tabel 2. Kondisi umum masyarakat peternak "Sympai Tampomas" 
Jurnal Pengabdian Masyarakat J-DINAMIKA, Vol. 4, No. 2, Desember 2019,

P-ISSN : 2503-1031, E-ISSN: 2503-1112

\begin{tabular}{|c|c|c|c|c|}
\hline \multirow[t]{2}{*}{ No } & \multicolumn{2}{|c|}{ Uraian } & \multirow{2}{*}{$\begin{array}{l}\text { Jumlah } \\
\text { Personil } \\
\text { (n) }\end{array}$} & \multirow{2}{*}{$\begin{array}{c}\text { Persentase } \\
(\%)\end{array}$} \\
\hline & Jenis & & & \\
\hline & kelamin & pria & $9 / 30$ & 30 \\
\hline & & wanita & $21 / 30$ & 70 \\
\hline \multirow[t]{5}{*}{2} & Pendidikan & & & \\
\hline & & $\begin{array}{l}\text { tidak } \\
\text { sekolah }\end{array}$ & $1 / 30$ & 3 \\
\hline & & SD & $20 / 30$ & 67 \\
\hline & & SMP & $6 / 30$ & 20 \\
\hline & & SMA & $4 / 30$ & 17 \\
\hline \multirow[t]{4}{*}{3} & Pemeliharaan & & & \\
\hline & & intensif & $17 / 30$ & 57 \\
\hline & & semi intensif & $5 / 30$ & 27 \\
\hline & & ekstensif & $8 / 30$ & 16 \\
\hline \multirow[t]{3}{*}{4} & Pakan & & & \\
\hline & & Hijauan & $23 / 30$ & 77 \\
\hline & & $\begin{array}{l}\text { Campuran } \\
\text { hijauan dan } \\
\text { konsentrat }\end{array}$ & $7 / 30$ & 23 \\
\hline \multirow[t]{2}{*}{5} & $\begin{array}{l}\text { Pencatatan } \\
\text { siklus }\end{array}$ & dilaksanakan & $6 / 30$ & 20 \\
\hline & $\begin{array}{l}\text { reproduksi } \\
\text { kambing } \\
\text { betina }\end{array}$ & $\begin{array}{l}\text { Tidak } \\
\text { dilaksanakan }\end{array}$ & $24 / 30$ & 80 \\
\hline
\end{tabular}


Data dasar kondisi sangat diperlukan untuk mengetahui situasi dan kondisi masyarakat setempat sebelum melakukan kegiatan penyuluhan. Kondisi awal yang diperoleh dapat dijadikan sebagai sumber informasi untuk menentukan materi atau subtansi yang diperlukan oleh masyarakat dan metode yang akan digunakan untuk penyampaian sehingga penyuluhan yang diberikan sesuai dengan kebutuhan mereka. Berdasarkan hasil yang diperoleh, kondisi masayrakat pada umumnya memiliki tingkat pendidikan yang kurang memadai, sehingga penyampaian materi perlu dilakukan dengan sederhana dan menggunakanistilah-istilah yang mudah dimengerti.Kondisi umum peternakan masih dikelola secara tradisional, dengan didomestikasi di kendang dekat rumah tanpa diberi area untuk penggembalaan dengan diberi pakan seadanya yang diperoleh dari kebun. Kondisi demikian, akan memberikan dampak pada kesehatan ternak yang kurang baik.

Secara lebih lanjut, maka diberikan kuisioner untuk mengukur tingkat pengetahuan peternak terhadap aplikasi manajemen reproduksi pada peternakan kambing perah meliputi: penanganan dara, perkawinan, kebuntingan, pasca kelahiran dan laktasi. Pada umumnya masyarakat masih belum mengenal aplikasi teknologi reproduksi dan masih mengelola peternakan secara tradisional. Hasil menunjukkan bahwa pada umumnya masayrakat sudah cukup memiliki pengetahuan yang cukup baik tentang seleksi induk, pemberian pakan, perawatan induk saat laktasi,perkandangan dan perawatan kesahatan ternak penganan pasca lahir dan pasca laktasi, namun pengetahuan mengenai penanganan induk saat berahi pertama dan perkawianan kembali pasca melahirkan masih cukup minim (Gambar 1). Selanjutnya dilakukan penyuluhan kepada warga mengenai hal tersebut dengan tatapmuka dan tanya jawab secara langsung. Masyarakat kelompok tani "Simpay Tampomas" cukup antusias dalam mengikuti kegiatan PKM yang telah diselenggarakan

Berdasarkan kondisi umum yang diperoleh, maka diberikan kuisioner untuk mengukur tingkat pengetahuan peternak terhadap aplikasi manajemen reproduksi pada peternakan kambing perah meliputi: penanganan dara, perkawinan, kebuntingan, pasca kelahiran dan laktasi. Pada umumnya masyarakat masih belum mengenal aplikasi teknologi reproduksi dan masih mengelola peternakan secara tradisional. Hasil menunjukkan bahwa pada umumnya masayrakat sudah cukup memiliki pengetahuan yang cukup baik tentang seleksi induk, pemberian pakan, perawatan induk saat laktasi,perkandangan dan perawatan kesahatan ternak penganan pasca lahir dan pasca laktasi, namun pengetahuan mengenai penanganan induk saat berahi pertama dan perkawianan kembali pasca melahirkan masih cukup minim (Gambar 1). Selanjutnya dilakukan penyuluhan kepada warga mengenai hal tersebut dengan tatapmuka dan tanya jawab secara langsung. Masyarakat kelompok tani "Simpay Tampomas" cukup antusias dalam mengikuti kegiatan PKM yang telah diselenggarakan

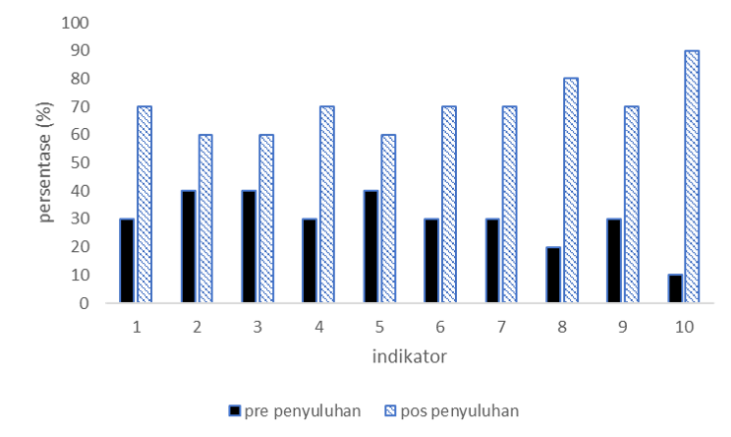

Gambar 1. Grafik Tingkat pengetahuan masyarakat kelompok tani "Sympai Tampomas" terhadap manajemen dan aplikasi teknologi reproduksi pada peternakan kambing perah. 1. Tata cara seleksi bibit dan indukan kambing perah 2. Tata laksana perawatan kambing dara yang meliputi deteksi estrus dan manajemen perkawinan pertama Tata laksana perawatan kambing dara yang meliputi deteksi estrus dan manajemen perkawinan pertama 3 . Tata laksana perawatan induk kambing perah pada saat kebuntingan Tata laksana perawatan induk kambing perah pada saat kebuntingan 4. Tata laksana perawatan induk kambing perah pada saat kelahiran 5. Tata laksana perawatan induk kambing perah pada saat laktasi 6. Penanganan induk saat estrus pertama dan perkwinan pertama pasca melahirkan 7. Penanganan anak pasca lahir dan pascasapih 8. Manajemen pemberian pakan Manajemen pemberian pakan 9. Manajemen perkandangan 10. Aplikasi teknologi reproduksi, sinkronisasi berahi dan IB

Di akhir kegiatan penyuluhan dilakukan post tes, hasil menunjukkan bahwa terjadi peningkatan pengetahuan masyarakat kelompok ternak terhadap aplikasi manajemen reproduksi. Peningkatan pengetahuan yang cukup significan adalah dalam hal Penanganan induk saat estrus pertama dan perkwinan pertama pasca melahirkan,penanganan pasca lahir dan pasca sapih serta aplikasiteknologi reproduksi, sinkronisasi berahi dan IB (Gambar 1). Perubahan perilaku masyarakat untuk mengaplikasikan manajemen dan teknologi reproduksi belum ada, karena pada awal kegiatan kami hanya melakukan survey dan melakukan penyuluhan. 


\section{KESIMPULAN}

Secara umum, anggota kelompok Tani "Sympai Tampomas" telah memili pengetahuan tentang aplikasi manajemen reproduksi pada pengelolaan kambing perah walaupun masih terbatas pada beberapa aspek. Pengetahuan peternak mengalami peningkatan yang cukup signifikan setelah dilakukan kegiatan penyuluhan.

\section{UCAPAN TERIMA KASIH}

Terimakasih kami ucapkan kepada DRPMI UNPAD yang telah memberikan dana pada kegiatan ini melalui skema PPM Prioritas 2018.

\section{DAFTAR PUSTAKA}

[1] Amiyati.. 2001. Petensi Susu Kambing sebagai Obat dan Sumber Protein Hewani untuk Meningkatkan Gizi Petani. Temu Teknis Fungsional non Peneliti. Hal. 13-17. Balai Penelitian Ternak. Bogor.

[2] Badan Pusat Statistik., 2013. Populasi Ternak yang Dipelihara oleh Rumah Tangga Usaha Peternakan Sesuai Jenis Ternak yang Diusahakan Menurut Wilayah dan Jenis Ternak - Indonesia. www.bps.go.id

[3] Davendra, C. dan Burns, M., 1994. Goat Production in the Tropic. Common Wealth. Agriculture Bureaux. Farnham Royal, England.

[4] Widyastuti R., Winangun, K., Wira, D.W., Ghozali, M., Syamsunarno, M.R.A.A., 2017. Tingkat pengetahuan dan pespon peternak kambing perah terhadap penyakit hewan (Studi Kasus: Kelompok Tani Simpay Tampomas Cimalaka Sumedang), Dharmakarya. 6(2), pp: 89-92.

[5] Yunita, D., Widyastuti, R.., Syamsunarno, M.R.A.A., Rasad, S.D., dan Indika, D.R., 2017. Pembagian Peran Dan Pengambilan Keputusan Dalam Rumah Tangga Peternak Kambing Perah Di Desa Cilengkrang Kecamatan Cimalaka Kabupaten Sumedang). Jurnal Ilmu Ternak. 17(1), pp: 2126. 